\title{
Social Networking Experiences on Facebook: A Study on the Students' of Comilla University
}

\section{Md. Belal Hossain, Comilla University, Bangladesh}

\begin{abstract}
This study is to identify the students' experiences on the uses of their favourite social networking site like Facebook and its effect on their daily life. In this paper, a survey was conducted by ninety five (95) students' from the six faculties of the Comilla University are taken as samples. Data were collected by using a questionnaire during July to August 2016.Most of the respondents reported that a constructive effects of using social networking sites is evident in their daily life. This study significantly found that they used Facebook for communication with their friends and others, getting information, educational purpose, sending birthday greetings, job purpose and entertainment etc. This study also suggested that there is a need for higher education policy makers in Bangladesh to properly connect the students' involvement in social networking to their academic purposes.
\end{abstract}

Keywords: Social networking; Facebook; Students' experiences; Comilla University; Technology. 


\section{Introduction}

Recently, the world has been shaped and updated by the development of the Internet. The progressive evolution of the Internet has made it become the most popular communication medium. A large portion of the people in the world is connected by social networks through the Internet (Oye et al., 2012).Social networking websites are the technological tool used by Internet users to as a platform to develop eventually mutual relationships for personal interests, business, games or academic purposes (William, 2009). From a global perspective, the number of social networking sites is used as a channel for transforming multiple areas of knowledge (Shohrowardhy and Hassan, 2014). The networking through internet particularly the Facebook has become popular with the pace of the global arena. Young people of the country has been using Facebook for social networking purpose more in the recent time. Considering this reality, this study has been conducted to provide descriptive information about the use of social networking sites by the university students. Fundamental questions for understanding the use of such applications address time commitment, why university students use these sites, how they interact on these sites, and the nature of their influence on the development of identity and friendship. Here, it has been considered these questions with respect to Facebook, a popular social networking site.

\section{Social Networking}

Social networking has been a common use on the internet in today's generation. Throughout the past, we had social networking sites which did not make it uphold a longer life than those which have ended up being very popular. Social networking websites are Facebook, YouTube, Twitter, Myspace, Friendster, LinkedIn, Live Journal, and Bebo, are memberbased Internet groups that allow users to post profile information, such as a username and photograph, and to communicate with others in innovative ways such as sending public or private messages or sharing photos. These sites disclose important information about how university students are interacting with one another in the information age.

\section{Social Networking in Bangladesh}

Bangladesh is one of Asia's giants of LDC's consisting of more than 160 million people. $50 \%$ of the people in Bangladesh maintain their living standards below the international poverty line (UNICEF Report, 2012). 5\% of the people (approximately 33.43 million people) 
of our country are habituated to use the Internet and out of them 95\% use mobile devices to connect to social networks. In Bangladesh, Facebook and YouTube are the most useful social networking sites. The penetration growth rate of social networking in Bangladesh is $2 \%$ or around 50,000 people per year. Based on our national economics, Bangladeshi people are not still familiar with social networking due to the limited income level since an hour of Internet access in an Internet cafe in Bangladesh costs the equivalent of $70 \%$ of the average daily income (www.wearesocial.net/Statistics). There is a dominant age group (18 24) in the user pool of social networking (Shohrowardhy and Hassan, 2014).

\section{Facebook}

According to 2008 edition of the Collins English Dictionary, Facebook is, "a popular social networking website", and as a verb, meaning "to search for (a person's profile) on the Facebook website.”Facebook (www.Facebook.com) is a free-access social networking website that is operated and privately owned by Facebook, Inc. Users can join networks organized by city, workplace, school, and region to connect and interact with other people. People can also add friends and send them messages, and update their personal profile to notify friends about themselves. Facebook gives the opportunity to chat with friends, upload photos or videos, share anything, and create page or applications.

Facebook is one of the important social media that promotes the exchange of messages between people across the world. Facebook.com originated in February, 2004 to facilitate social interaction exclusively among college students by Mark Zuckerberg.There are over 500 million users in the world with a population of 6.8 billion, which means that about 1 out of 14 people have a Facebook account. According to Mark Zuckerberg, "If Facebook were a country, it would be the 6th most populated country in the world."

Mark Zuckerberg along with Dustin Moskovitz, Chris Hughes and Eduardo Saverin founded Facebook while they were students of Harvard University in February 2004. Initially, its membership was limited to Harvard students. Then it expanded to other colleges, it later expanded further to include any university student. In September 2005 Facebook was expanded to high school students, and, finally, in September 2006, to anyone aged 13 and over. Now Facebook has over 700 employees and the directors' board is consisted of seven 
members. On $1^{\text {st }}$ January 2009, according to the Facebook statistics it has over 140 million active users all over the world. The headquarter of the company is in Palo Alto, Calif. U.S. (https://en.wikipedia.org/wiki/Facebook).

\section{Literature Review}

Previous studies have found that more than $90 \%$ of university students use Facebook. Roknuzzaman (2006) has conducted a survey on internet access in a large public university. Mostofa (2011) has scanned the access and use of internet among business studies students of a private university of Bangladesh. Mahmud (2011) has checked up the private university student's attitudes towards internet; Alam (2013) has investigated the future prospect of '3G' network in Bangladesh. Rahaman, Ullah and Shafayet (2013) have explored the factors that are influencing Facebook privacy awareness of Bangladeshi undergraduate university students. But none of them have investigated the effects of the use of social networking sites on students' academic perspective. Asad, Mamun \& Clement (2012) who have surveyed the effect of social networking sites to the lifestyles of teachers and students; on the other hand, apart from Bangladesh few study have found on Facebook. In one study, U.S. college students reported using Facebook an average of 10 to 30 min daily (Ellison, Steinfield, \& Lampe, 2007). Another study found that about half of 12-17 year olds with social networking site memberships log on daily: 22\% logged on to social networking sites several times per day, $26 \%$ once a day, $17 \%$ three to five days per week,15\% one or two days per week, and only $20 \%$ every few weeks or less (Lenhart \& Madden, 2007). A recent survey of college students in the U.S. showed that social networking sites are used for social interaction with offline acquaintances in order to maintain friendships rather than to make new friends (Ellison et al., 2007).

Among those surveyed in college, the use of such sites is nearly universal. For example, a large survey of college students from several universities in the Midwest U.S. found that 91\% of respondents use the site Facebook.com (Wiley \& Sisson, 2006). Most of the students originally activated their Facebook account during the summer before college (53.26\%), though some did so after they began college (38.04\%). On average, respondents had been using Facebook for about 2 years $(M=24.32$ months, $S D=9.93)$. Only students who had a 
Facebook account participated in this study, but almost all of the students in the classes were members of Facebook. (Ellison et al., 2007; Wiley \& Sisson, 2006).

Another study found that, students would often use the Facebook walls to describe and sometimes deliberate on their most recent instances of the university experience - be it lectures, seminars or, on occasion, library visits and individual encounters with teaching staff. For example, students would use Facebook to 'go over' their experiences of recently finished lectures. (Selwyn, 2009)

Moreover, graduate and undergraduate students also use social networking sites to ask questions about their field of the study and to make evaluations between class materials and the experience from the field. But yet in the context of Bangladesh, there has hardly been any study about effects of using Facebook of the students in the university level. By these literatures, students are benefited from the use of Facebook, but what are the actual benefit of the students who use Facebook for their individual purposes? How they use Facebook? This study is focused on these research questions.

\section{Theoretical Framework}

To find a proper theory to analyze Facebook is difficult. But from the using perspective this study has analyzed Facebook with the 'uses and gratifications' framework. The main theme of uses and gratifications theory is that audience is active and media use can be conceived of as goal directed and competing with other sources of need satisfaction. Blumler and katz's landmark volume 'the uses of mass communications' in 1974, brought a revolution to media research. Most of the theories on media explained about the effects media had on people. This theory explained that how people use media for their need and gratification. In other words, this theory states what people do with media rather than what media does to people. According to uses and gratification theory, it is not so people make use of the media for their specific needs. This theory can be said to have an audience-centered approach. They gain more knowledge by using media. There are several needs and gratification for people they are categorized into: Cognitive needs,Affective needs,Personal Integrative needs, Social Integrative needs and, Tension free needs. 
This study has tried to find out the gratifications offered by usingFacebook. Specially, gratifications attract the users in to the Facebook.

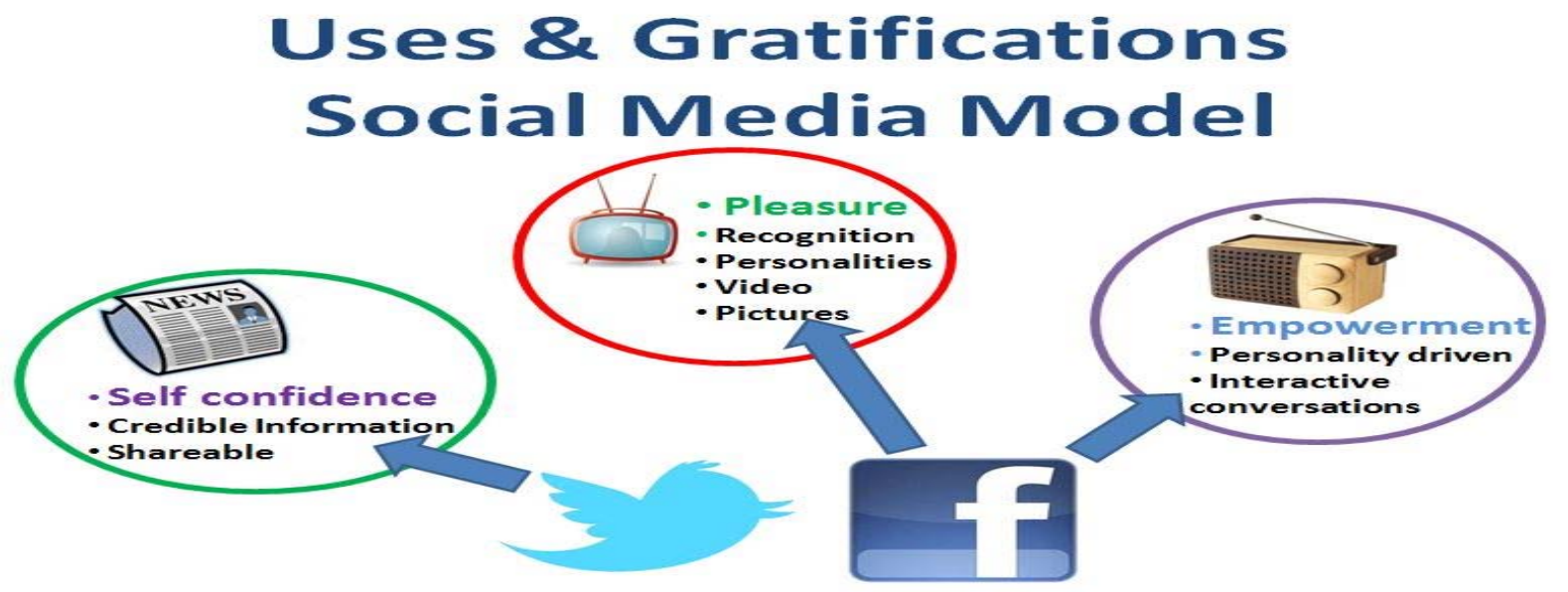

(https://timothyblotz.files.wordpress.com/2013/07/uses-gratifications-social-media-model1.jpg)

\section{Objectives of the study}

The general objectives of the study is to explore the students' social networking experiences on Facebook. The specific objectives of the study are:

1. To find out the effects of using Facebook.

2. To identify the advantages and disadvanges of using Facebook, And

3. To find out the limitations of using Facebook.

\section{Study Methods}

\section{Nature of the Study}

The survey method had been applied to conduct the study. Survey methods often are the sole way of retrieving information about a respondent's past history for instance, his sexual behavior, childhood experiences, and recreational activities (Kahn \& Cannell, 1968). As Richardson and his associates have indicated (1965), surveys provide one of the few techniques available for the study of attitudes, values, beliefs and motives (Galtung, 1967). 


\section{Sampling Procedure}

This study was conducted the survey among ninety five (95) students' (57 male and 38 females) from the six faculties of 19 disciplines are taken as samples. Five students from the each department with three males and two females, analyzed in quantitative and qualitative standard. The majority of students studying of those faculties are aged between 18- 25 years, just over three-quarters are females. They were selected according to their level of experiences of using social networking sites, especially on Facebook .This research conducted on purposive sampling. By purposive analysis, it is to be seen the effects of using Facebook at the students’ of Comilla University.

\section{Data Collection}

This study wasconducted through questionnaire survey method using both open-ended and close ended questions. According to Moser and Kalton, "The relative merits of open and precoded questions have been the subject of a good deal of research, particularly in the case of attitude analysis” (Moser and Kalton, p. 341-46).

Both primary and secondary data were used in the study. In order to collect primary data, a questionnaire was designed in the light of the objectives of the study. The active period of data collection took place between on Sunday July 02, 2016 to Thursday August 02, 2016.

Primary data: Primary data were collected from the 95 graduate and undergraduate students' of the Comilla University, conducting a survey through questionnaire for the first time.

Secondary data: Secondary data were collected from different sources like articles from both national and international recognized journals, texts, websites and periodicals published in the daily newspaper etc.

\section{Findings and Analysis}

\section{Presentation of Personal Data of Respondents}

This study has 95 samples. Here, the data has been considered as basic characteristics of the respondents. They are: respondents' name, age, profession, sex, department, academic year, address, internet facility and the time of being member of the Facebook. 


\section{Sex of the Respondents}

To get variation in the data, it was tried to gather data equally from both sex groups. It is almost achieved as there are $60 \%$ male respondents and $40 \%$ female respondents. The detailed data are presented in the table-01.

\section{Table -01: Distribution of the Sex by the Respondents}

\begin{tabular}{|l|l|l|}
\hline Sex & Number of Respondents & Percentages (\%) \\
\hline Male & 57 & $60 \%$ \\
\hline Female & 38 & $40 \%$ \\
\hline Total & 95 & $100 \%$ \\
\hline
\end{tabular}

Source: Field survey, 2016.

\section{Effects of Using Facebook}

Data shows that $50 \%$ respondents have moderate effects by using Facebook, while 21\% respondents mentioned very much effects, $16 \%$ slight effects, $7 \%$ much effects and $6 \%$ very slight effects by using Facebook in their daily life. The detailed data are presented in the figure-01.

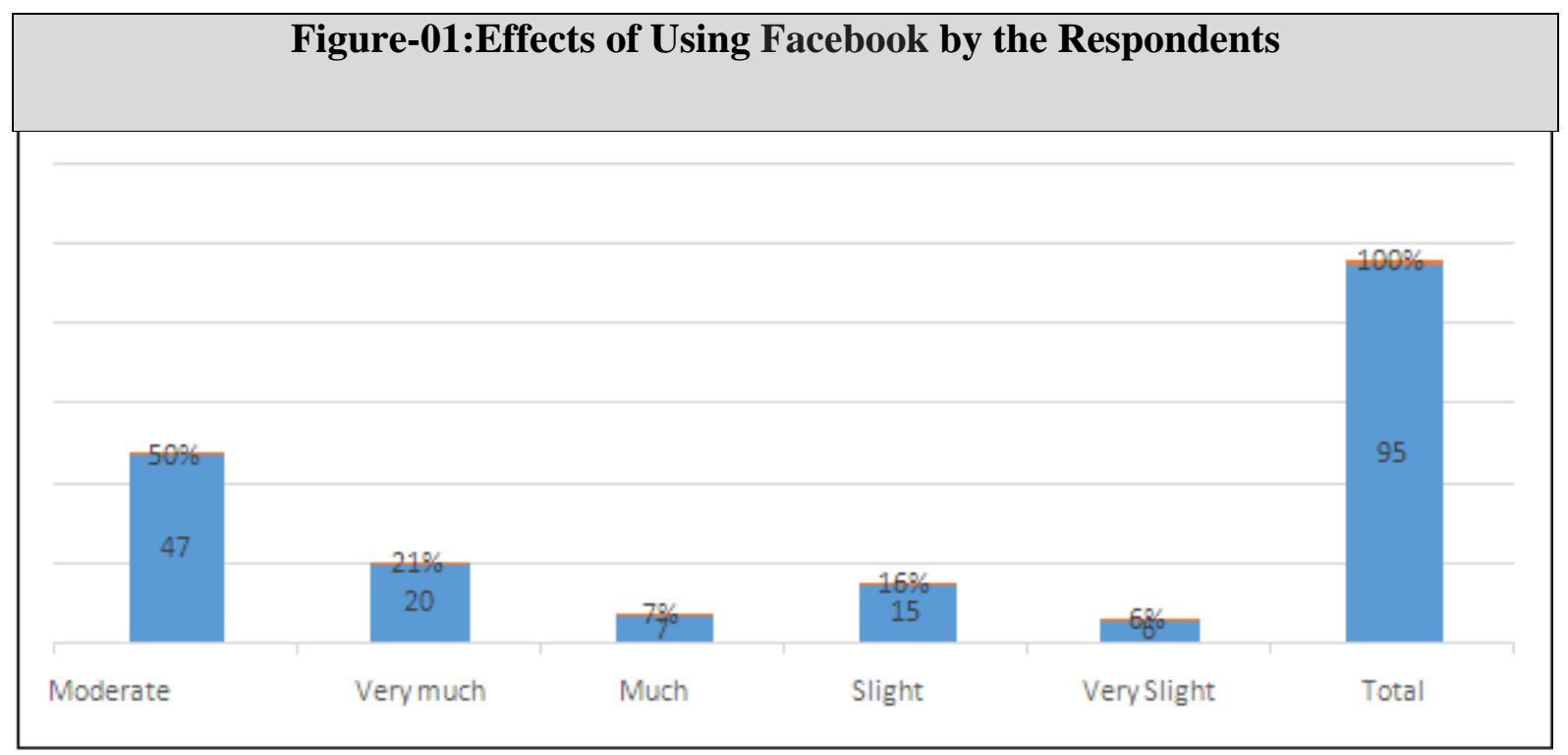

Source: Field survey, 2016. 


\section{Advantages of Using Facebook}

Social networking sites have become prominent in the society and integrated into our everyday lives. It is very suitable and effective to communicate with people around the world. Specially, Facebook initiate learning through the exchange of messages and the sharing of links, information, and resources. It has online sources where people can stay socially connected to their friends, family, peers, and acquaintances. Students also gets educational and social information, updated with contemporary world, reduces communication cost, developed social network systems, remove loneliness and also find different job related information by using Facebook. As seen by table-03 shows that $33 \%$ respondent used Facebook for sharing getting educational and social information, 27\% for stay connected with their friends, $13 \%$ for updated with contemporary world, $12 \%$ for social networking, for remove loneliness and $7 \%$ only for job related information, $17 \%$ for entertainment and others. The detailed data are presented in the table- 02 .

\begin{tabular}{|l|l|l|}
\hline \multicolumn{2}{|c|}{ Table-02:Advantages of Using Facebook by the Respondents } \\
\hline Advantages of Facebook & Number of Respondents & Percentages (\%) \\
\hline $\begin{array}{l}\text { Getting Educational and Social } \\
\text { Information }\end{array}$ & 31 & $33 \%$ \\
\hline Stay Connected with Friends & 26 & $27 \%$ \\
\hline Updated with Contemporary World & 12 & $13 \%$ \\
\hline Develop Social Networking Systems & 11 & $12 \%$ \\
\hline Getting Job Related Information & 7 & $7 \%$ \\
\hline Others & 16 & $17 \%$ \\
\hline
\end{tabular}

Source: Field survey, 2016.(Multiple Responses)

\section{Opinion on Disadvantages of Using Facebook}

On the other hand, there are many disadvantages of using Facebook. First, privacy becomes an issue because the respondent post and share personal information on the internet, and anybody can view the sites. Also, Facebook can become time consuming and addictive when people develop the habit of always talking to people on the internet for long periods of time. Finally, Facebook creates a barrier to communication because even though the internet is a 
convenient and efficient medium to converse, emotions, feelings, and facial expressions are lost during communication. People are unable to see how others react to their messages and hear their tones of voice because they are not speaking face-to face, and messages may be impersonal when sending them online. As seen in figure-02shows that $76 \%$ respondents replied that there are disadvantages of using Facebook. But 24\% respondent don't think so.

\section{Figure-02: Disadvantages of Using Facebook by the Respondents}

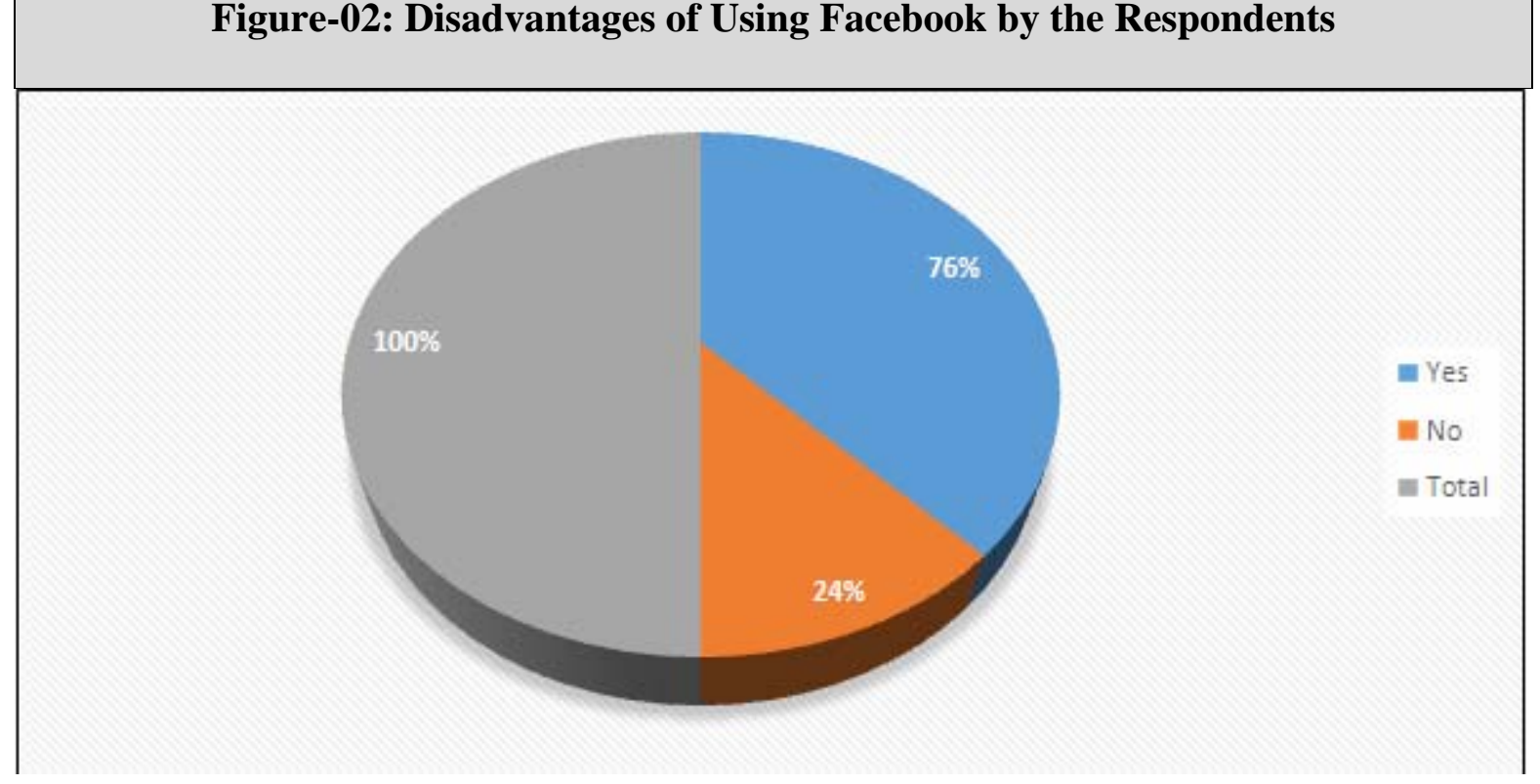

Source: Field survey, 2016.

\section{Limitations of Using Facebook}

There are several limitations of using Facebook. For example, would take far more time with a slow internet connection, expensive internet megabyte, less security of personal pictures, sometimes harassment by the hackers etc. As seen in table-03 shows that $42 \%$ faces for study hampered, $26 \%$ for wastage of time, $21 \%$ discloses of political views and others.16\% respondents think that expensive internet megabyte, $11 \%$ faces huge friend requesting problems.

Table-03: Limitations of Using Facebook by the Respondents

\begin{tabular}{|l|l|l|}
\hline Limitations of Facebook & Number of Respondents & Percentages (\%) \\
\hline Expensive Internet Megabyte & 15 & $16 \%$ \\
\hline Huge Friend Request Accepting & 10 & $11 \%$ \\
\hline
\end{tabular}


Volume: 7 - Issue: 3 July - 2017

\begin{tabular}{|l|l|l|}
\hline Wastage of Time & 25 & $26 \%$ \\
\hline Hampered Study & 40 & $42 \%$ \\
\hline Political Views and Others & 20 & $21 \%$ \\
\hline
\end{tabular}

Source: Field survey, 2016. (Multiple Responses)

\section{Reasons for Using Facebook}

Data show that students answered an open-ended question about their reasons for using Facebook. Most of the respondents (67\%) used Facebook for entertainment and communication, getting information , educational purpose and getting old friends, updated with friends and being closed with friends, sending birthday greetings etc. 16\% used only for communication, $12 \%$ for getting information, $8 \%$ entertainment and communication, $4 \%$ for gossip and time passing. The data are presented in the table-04.

\begin{tabular}{|l|l|l|}
\hline \multicolumn{2}{|c|}{ Table -04: Reasons of Using Facebook by the Respondents } \\
\hline Reasons of Facebook of & $\begin{array}{l}\text { Number } \\
\text { Respondents }\end{array}$ & Percentages (\%) \\
\hline $\begin{array}{l}\text { Communication, Getting Information, } \\
\text { Educational Purpose and Getting Old } \\
\text { Friends, Updated with Friends and Being } \\
\text { Closed with Friends, Sending Birthday } \\
\text { Greetings, Job Purpose and } \\
\text { Entertainment etc. }\end{array}$ & $64 \%$ \\
\hline Communication & 15 & $16 \%$ \\
\hline Getting Information & 11 & $12 \%$ \\
\hline Entertainment and Communication & 7 & $8 \%$ \\
\hline Gossip and Time passing & 4 & $4 \%$ \\
\hline Source: Field survey, 2016. (Multiple Responses) & \\
\hline
\end{tabular}




\section{Information Sharing in the Facebook}

Data shows that $77 \%$ respondents shared their name, gender, email address, picture, high school, college and their university name, birthday, political view, religion, country, phone number and relationship status. 17\% shared favorite music, books, movies and TV shows, but 6\% students shared no information in their Facebook account. The data are presented in the table-05

\begin{tabular}{|l|l|l|}
\hline \multicolumn{2}{|c|}{ Table-05: Information Sharing in the Facebook by the Respondents } \\
\hline Information & Number of Respondents & Percentages (\%) \\
\hline $\begin{array}{l}\text { Name, Gender, Email, Picture, High } \\
\text { School, College, University, } \\
\text { Birthday, Major Interests, Political } \\
\text { View, Religion, Country, Phone } \\
\text { Number and, Relationship Status }\end{array}$ & 73 & $77 \%$ \\
\hline $\begin{array}{l}\text { Favorite Music, Books, Movies } \\
\text { and TV Shows }\end{array}$ & 16 & $17 \%$ \\
\hline \begin{tabular}{l} 
No Information \\
\hline
\end{tabular} & 6 & $6 \%$ \\
\hline
\end{tabular}

Source: Field survey, 2016. (Multiple Responses)

\section{Duration of Using Facebook}

Data show that the total time spends on Facebook was dispersed throughout the day. In response to an open-ended questions, most of the respondents (27\%) spend one and two hours per day by using Facebook, 22\% passed three hours, 5\% four hours, 2\% five hours and 17\% spend above five hours by using Facebook. The data are presented in the figure-03: 


\section{Figure-03: Duration of Using Facebook by the Respondents}

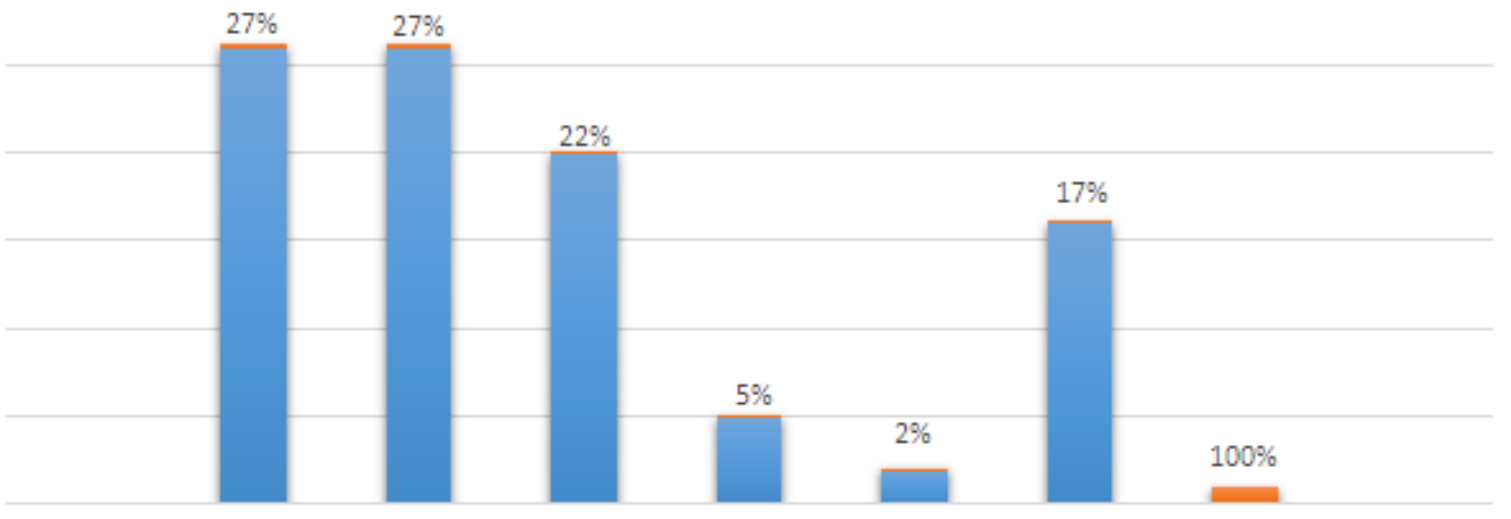

One hours Two hourThree hoursour hoursFive hoAtsove five hoursotal=

Source: Field survey, 2016.

\section{Interest of Using Facebook}

Another open-ended question asked students what they found most interesting about Facebook. There was a great deal of variability in responses to this question. As seen in table-06, 40\%respondents are moderate interesting of using Facebook, 33\% very interesting, $10 \%$ very high Interesting, $12 \%$ less interesting and, $5 \%$ are not interesting about Facebook.

\begin{tabular}{|l|l|l|}
\hline \multicolumn{3}{|c|}{ Table-06: Interest Level of Using Facebookby the Respondents } \\
\hline Level of Interest & Number of Respondents & Percentages (\%) \\
\hline Very High Interesting & 10 & $10 \%$ \\
\hline Very Interesting & 31 & $33 \%$ \\
\hline Moderate Interesting & 38 & $40 \%$ \\
\hline Less Interesting & 11 & $12 \%$ \\
\hline Not Interesting & 5 & $5 \%$ \\
\hline Total & 95 & $100 \%$ \\
\hline
\end{tabular}

Source: Field survey, 2016. 


\section{Internet Using Facility}

Data show that $71 \%$ respondents replied that they used internet by their Mobile phone for using Facebook, 5\% using Laptops, 18\% using Mobile and Laptop, 3\% using Mobile and Desktop. The detailed data are presented in the figure-04:

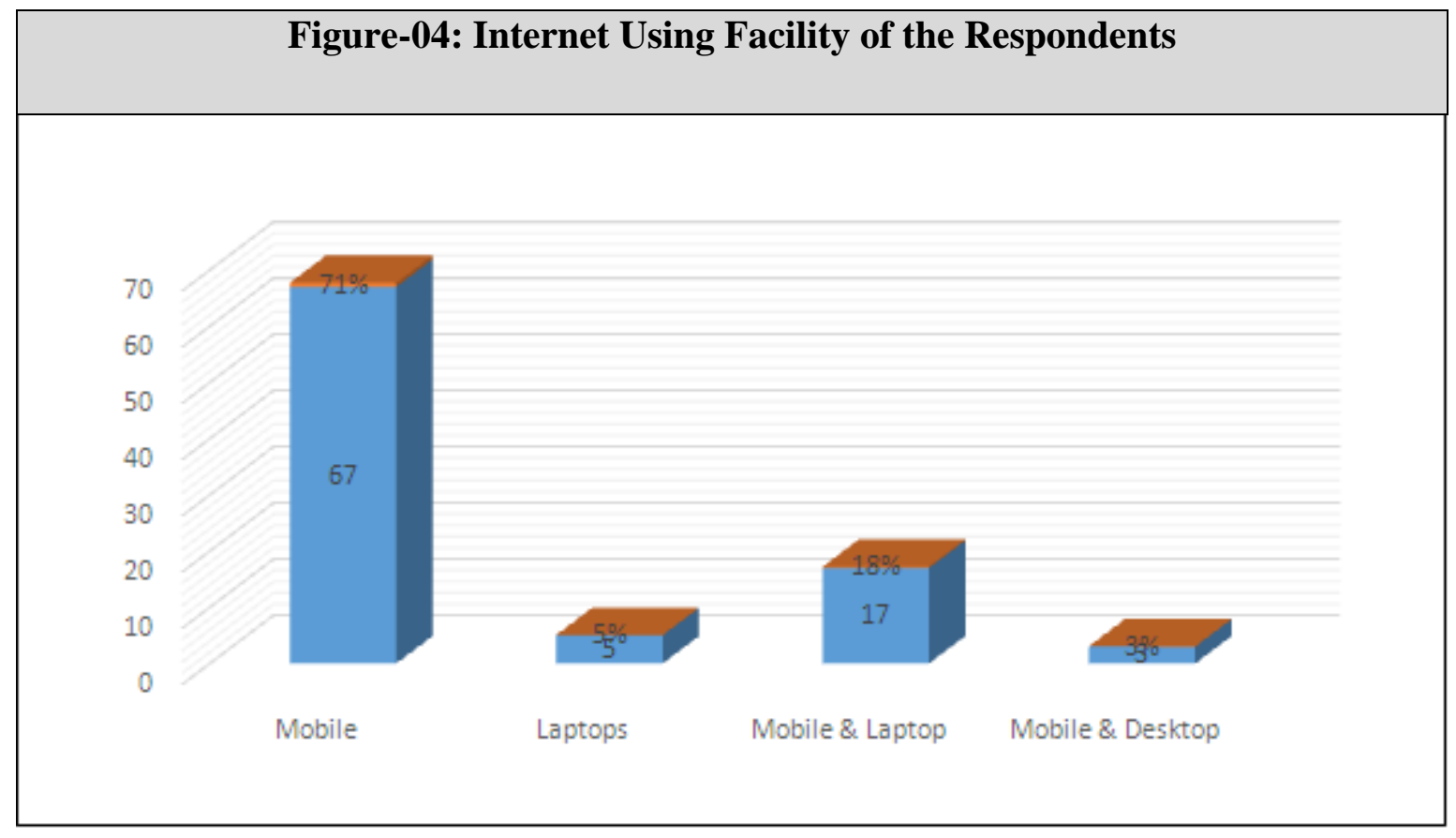

Source: Field survey, 2016.

(Multiple Responses)

\section{Time of Being Member of Facebook}

Facebook using is relatively new practice in Bangladesh. However, $16 \%$ of the respondents became member of Facebook one year ago.15\% respondents opened Facebook before two years, $16 \%$ respondents opened before three years,17\% respondents opened before four years ,11\% before five years, $15 \%$ opened more than five years ago. The detailed data are presented in the table-07:

\begin{tabular}{|l|l|l|}
\hline \multicolumn{2}{|l|}{ Table-07: Opening Time of Facebook Account by the Respondents } \\
\hline Duration & Number of Respondents & Percentages (\%) \\
\hline 1 year & 15 & $16 \%$ \\
\hline 2 years & 14 & $15 \%$ \\
\hline 3 years & 15 & $16 \%$ \\
\hline
\end{tabular}


Volume: 7 - Issue: 3 July - 2017

\begin{tabular}{|l|l|l|}
\hline 4 years & 16 & $17 \%$ \\
\hline 5 years & 11 & $11 \%$ \\
\hline Above 5 years & 14 & $15 \%$ \\
\hline
\end{tabular}

Source: Field survey, 2016. (Multiple Responses)

\section{Number of Account Holders in the Facebook}

Data shows that $78 \%$ respondents have one Facebook account, $21 \%$ respondents have two Facebook accounts but only 1\% respondents have more than two Facebook accounts. The detailed data are presented in thefigure-05:

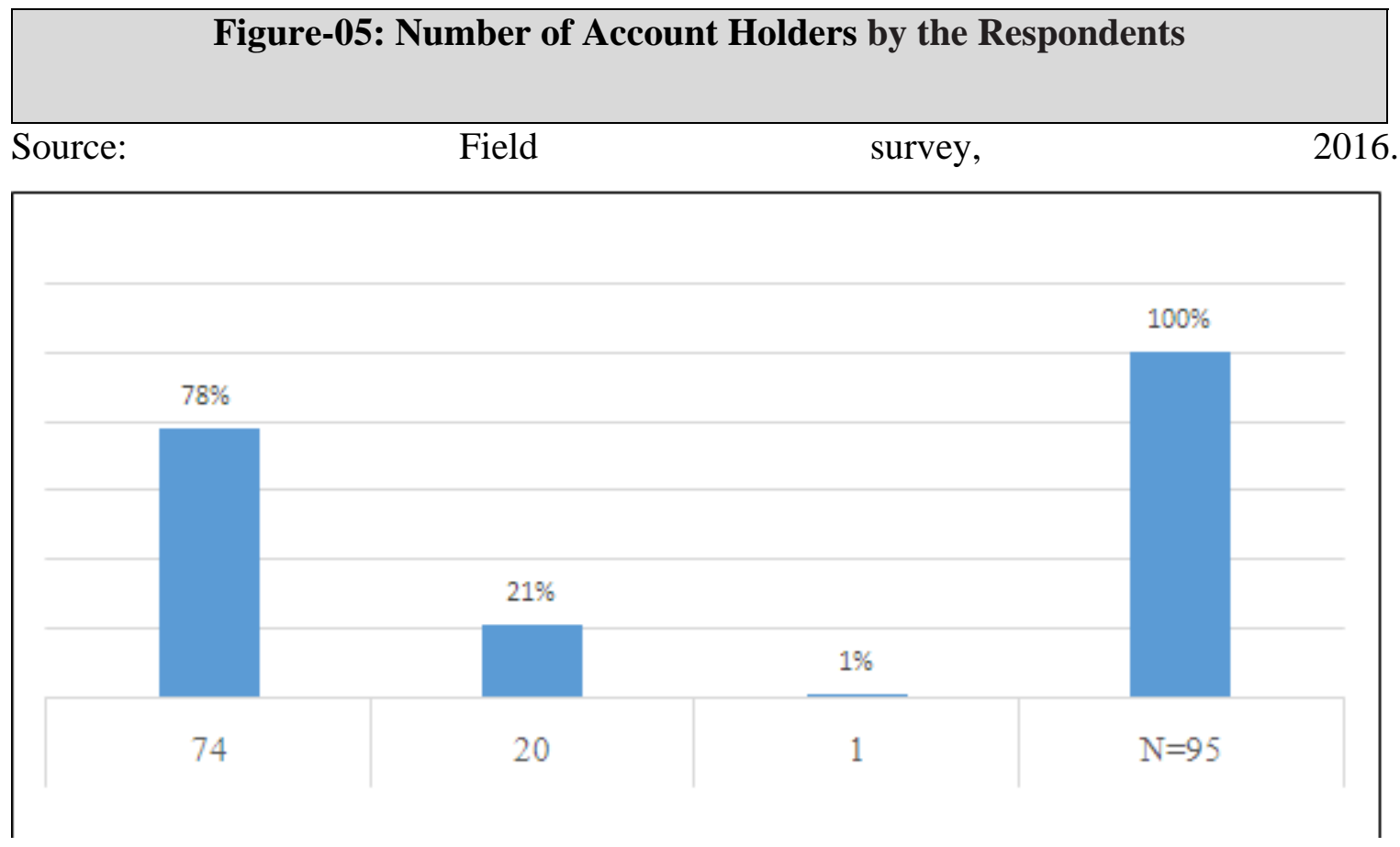

\section{Time of Using Facebook}

Most of the respondents (60\%) have no fixed time for using Facebook. A big portion (21\%) of the respondents uses Facebook at night, $10 \%$ use at morning, $5 \%$ use at afternoon, $4 \%$ use at evening. The detailed data are presented at the table-08: 
Volume: 7 - Issue: 3 July - 2017

\begin{tabular}{|l|l|l|}
\hline \multicolumn{3}{|c|}{ Table-08: Time of Using Facebook by the Respondents } \\
\hline Time & Number of Respondents & Percentages (\%) \\
\hline Morning & 9 & $10 \%$ \\
\hline Afternoon & 5 & $5 \%$ \\
\hline Evening & 4 & $4 \%$ \\
\hline Night & 20 & $21 \%$ \\
\hline No fixed time & 57 & $60 \%$ \\
\hline Total & 95 & $100 \%$ \\
\hline
\end{tabular}

Source: Field survey, 2016.

\section{Number of Friends in the Facebook}

One of the main advantages of using Facebook is the users' ability to make friends. The data show that users have many friends in Facebook. Out of 95 respondents, 60\% respondents have 1-500 friends, 17\% respondents have 500-1000 friends and another 17\% also have 1000-1500 friends, $2 \%$ have 1500-2000 friends and only 4\% have more than 2000 friends in their Facebook account. The detailed data are presented in the table-09:

\begin{tabular}{|l|l|l|}
\hline \multicolumn{3}{|c|}{ Table-09: Number of Friends in the Facebook by the Respondents } \\
\hline Number of Friends & Number of Respondents & Percentages (\%) \\
\hline $1-500$ & 57 & $60 \%$ \\
\hline $500-1000$ & 16 & $17 \%$ \\
\hline $1000-1500$ & 16 & $17 \%$ \\
\hline $1500-2000$ & 2 & $2 \%$ \\
\hline More than 2000 & 4 & $4 \%$ \\
\hline Total & 95 & $100 \%$ \\
\hline
\end{tabular}

Source: Field survey, 2016.

\section{Changing Time of Profile Picture}

Most of the respondent (48\%) changed their profile picture once a month , 10\% chanced once a week , $17 \%$ changed twice a week , $7 \%$ chanced three or more times a week but $18 \%$ of 
the respondent don't chance their profile picture in the Facebook. The detailed data are presented in the figure-06:

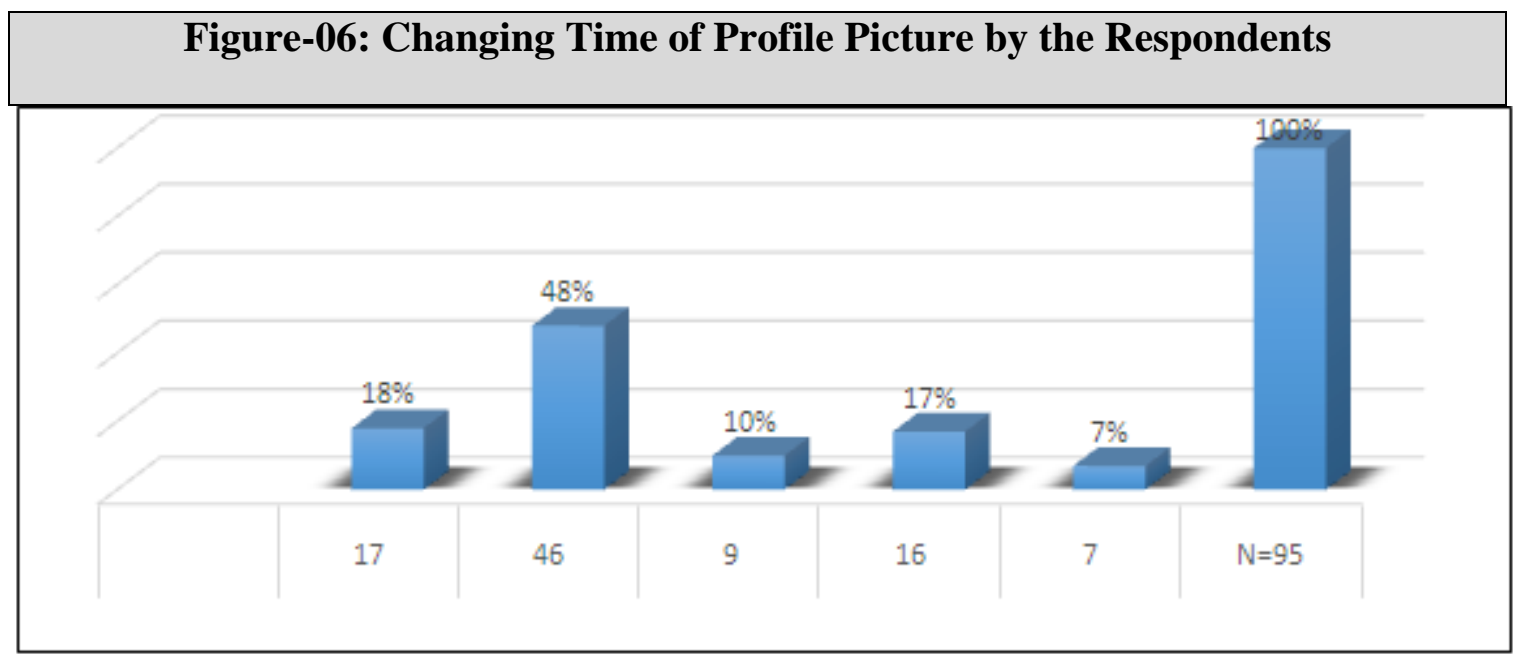

Source: Field survey, 2016.

\section{Visiting Time of Facebook in a Day}

Most of the respondent (29\%) visited their Facebook account 1-2times in a day, 22\% visited 2-3 times, 31\% used many times, 11\% used for 3-4 times, 7\% used for $4-5$ times and 31\% used for many times. The detailed data are presented in the figure-07:

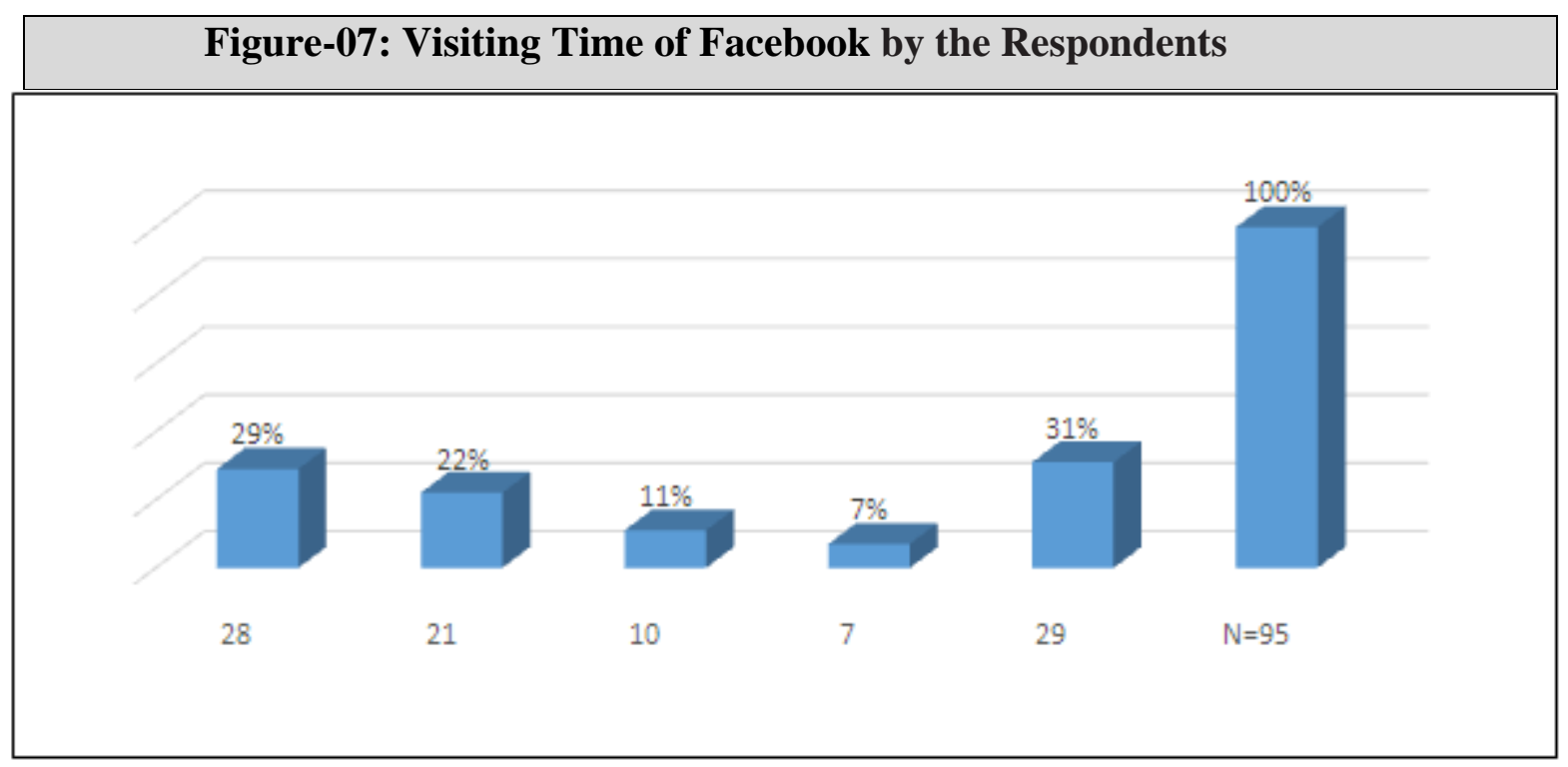

Source: Field survey, 2016. 


\section{Message of Comment in the Facebook Wall}

Data shows that most of the respondents (36\%) posted emotional, personal, professional, educational and social information on their Facebook wall, 28\% posted personal information, $11 \%$ posted social and political issues, $8 \%$ posted on different contemporary issues, $6 \%$ posted on emotional and educational information, only 5\% respondents posted professional information on their Facebook wall. The detailed data are presented in the table- 10 .

\begin{tabular}{|l|l|l|}
\hline \multicolumn{2}{|c|}{ Table-10: Message of Comment in the Facebook Wall by the Respondents } \\
\hline Comment & Number of Respondents & Percentages (\%) \\
\hline Emotional & 6 & $6 \%$ \\
\hline Personal & 27 & $28 \%$ \\
\hline Professional & 5 & $5 \%$ \\
\hline Educational & 6 & $6 \%$ \\
\hline Social and Political Issues & 10 & $11 \%$ \\
\hline Contemporary Affairs & 7 & $8 \%$ \\
\hline $\begin{array}{l}\text { Emotional, Personal, Professional, } \\
\text { Educational and Social information }\end{array}$ & 34 & $36 \%$ \\
\hline
\end{tabular}

Source: Field survey, 2016. (Multiple Responses)

\section{Discussion}

This study has investigated on what are the effects of students' using social networking site, especially on Facebook, why they use it, and how they interact with each other on this website, how much time they spent by using Facebook, what are the advantages and disadvantages of using Facebook, and what are the limitations of using this site. The demographic data shows that male students are more prone to use Facebook than female students. This study reveals that Facebook is the part of their everyday experiences, most of the respondents are using Facebook for sharing educational and social information, for staying connected with their friends and others, sending birthday greetings, job purpose and entertainment etc. This study found that most of the respondent also use Facebook for sharing personal identity such as name, gender, email, picture, high school, college, university, 
birthday, major interests, political view, religion, country, phone number and, relationship status etc. This study also suggested that there are a lot of disadvantages of using Facebook, such as discloses personal privacy of the users, very much time consuming and addictive when the users develop the habit of chatting others on the internet for long periods of time. The findings of this study are consisted with previous research conducted by Ellison et al. (2007) for U.S. College students. Here, 85\% of college students used Facebook to communicate with their friends and others, both on campus and from their former high schools. Facebook is clearly peer-to-peer communication. Another study suggested that Facebook provide a unique opportunity for students to display their personal identities, religion, and political ideology etc. (Arnett, 2000) .This study also suggest that the communication systems of the past are expanding in the modern age. Social networking sites like Facebook provide new venues for students to express themselves and to interact with one another. They are getting information by reading news feed about what friends are doing or looking at others' profiles or pictures. They also posted different information to their Facebook walls and posting pictures for others to observe in a public communication style.

\section{Conclusion}

This study goes to obtain the students' observations of the effects of using Facebook in their daily life. This study revealed that student's affiliation with Facebook in just a small proportion with academic usage. They are mostly driven by followed by social needs. Moreover, Facebook is used for different purposes such as fraud, transferring misinformation, unusual presentation and copy of the statements of people in order to create misunderstandings among the users. These patterns negatively affect the students and divert their concentration from academic purpose to others. So, the policy makers like the Ministry of Education and concerned authorities should assist the development of a digital education system that takes advantage of the potentially beneficial uses of Facebook for the academic purposes.There were several limitations of this study also. First, only one type of social networking site, particularly on Facebook was assessed here. It may be that other sites are used in different ways. Second, this study measures a specific group, primarily students attending a public university, who may differ from other Internet users in important ways, such as their easy access to fast Internet connections. Third, this study has been conducted within a short time frame with only 95 samples. Further research can be done on a wider 
Online Journal of Communication and Media Technologies

Volume: 7 - Issue: 3 July - 2017

scale with a large sample so that every aspect of using Facebook gets in-depth attention. This study has also been conducted with only the students of Facebook users. So,future research can be conducted on the general internet users to find the rate of using Facebook. 


\section{References}

Alam, M. S. (2013). 'Future Prospect of 3G Network in Bangladesh', National Conference on Need Assessment of B.Sc. Engineering in CSE Program, February 20, 2013.

Arnett, J. J. (2000). Emerging adulthood: A theory of development from the late teens through the twenties. American Psychologist, 55, 469-480

Asad, S., Mamun, M.A. and Clement, C.K. (2012).'The Effect of Social NetworkingSites to the Lifestyles of Teachers and Students in Higher Educational Institutions',International Journal of Basic and Applied Sciences, Vol. 1 Iss. 4, PP. 498-510.

Ellison, N. B., Steinfield, C., \& Lampe, C. (2007). The benefits of Facebook “friends:” Social capital and college students' use of online social network sites. Journal of ComputerMediated Communication, 12(4), 1143-1168.

Galtung, J. (1967). Theory \& Methods of Social Research. New York: Columbia University Press.

Https://en.wikipedia.org/wiki/Facebook).

Https://timothyblotz.files.wordpress.com/2013/07/uses-gratifications-social-media-model-

Kahn, R.L. and Cannell, C.F. (1968).The Dynamics of Interviewing. New York: Wiley.

Lenhart, A., \& Madden, M. (2007). Teens, privacy \& online social networks: How teens manage their online identities and personal information in the age of Myspace. Washington, DC: Pew Internet \& American Life Project.

Mahmud, M. A. A. (2011). 'Student's Attitudes towards Internet: A study on Private University of Bangladesh', European Journal of Business and Management, Vol. 3 Issn. 2222-1905(paper), Issn 2222-2839 (online).

Moser, C and Kalton, G (n.d).Survey Method in Social Investigation ( $2^{\text {nd }}$ ed). pp. 342-46.

Mostofa, Sk. M. (2011). 'Internet Access and Use among Business Students of a Private University of Bangladesh: A Survey', Annals of Library and Information Studies,58, 78-85.

Oye, N., Helou, A.M. and Rahim, Z.Z.A. (2012).“Students’ Perceptions on Social Networking Sites Influence on Academic Performance”, International Journal of Social Networking and Virtual Communities, Vol. 1, No. 1, pp. 715.

Rahaman, Arafatur, Ullah, G. M. Shafayet (2013). 'Exploration of Influencing Factors That Effecting Facebook Privacy Awareness On Bangladeshi Undergraduate University 
Student's', International Journal Of Scientific \& Technology Research,Volume 2, Issue 6, June 2013..047

Richardson, S. A. ET. Al. (1965). Interviewing. New York: Basic Books.

Roknuzzaman, M. (2006). 'A survey of Internet access in a large public university in Bangladesh', International Journal of Education and Development using Information and Communication Technology (IJEDICT), 2006, Vol. 2, Issue 3, pp.86-105.

Selwyn, Neil. (2009). 'Faceworking: exploring students' education-related use of Facebook', Shohrowardhy, H.S., Hassan, H.M.K. (2014). “Students' perception of social networking for academic purposes in Bangladesh”, Management \& Marketing.Challenges for the Knowledge Society, Vol. 9, No. 4, pp. 459470.

Wiley, C., \& Sisson, M. (2006, November). Ethics, accuracy and assumption: The use of Facebook by students and employers. Paper presented at the Southwestern Ohio Council for Higher Education Special Topics Forum, Dayton, $\mathrm{OH}$.

William, F.P. (2009). “Social networking sites: How to Stay Safe Sites”, Monthly Security tips Newsletter, Vol. 4, No. 3. 